\section{Domestic Gardens as Water-wise Landscapes: A Case Study in Southwestern Europe}

\author{
Rafael Fernández-Cañero ${ }^{1,3}$, José Ordovás ${ }^{1}$, \\ and Miguel Ángel Herrera Machuca ${ }^{2}$
}

ADDITIONAL INDEX WORDS. private gardens, xeriscape, best management practices, sustainable gardening, garden irrigation

\begin{abstract}
SUMMARY. Spain has undergone a period of uncontrolled urban expansion in a relatively short time-span, affecting people's quality of life in negative ways with significant impacts on the environment and land resources such as water and energy. Many new residential areas have low-density development, based on single-family houses with private gardens. These gardens are usually relatively small in size, but when considered as a whole, they make a substantial contribution to urban green spaces and have an important impact on the local environment. Although this includes a large variety of benefits, gardens demand a significant quantity of resources, including irrigation water, which is also important and should be taken into account. This paper analyzes features and management practices in domestic gardens, their relationships to garden design, and the attitudes of owners with regard to more sustainable alternatives. In addition, the main features of private gardens are examined. For this study, in-person interviews were conducted with homeowners who possess domestic gardens in the region of Aljarafe in southern Spain. The features of the gardens surveyed proved to be highly variable and related to several factors, such as the area of the gardens. Results seem to indicate that owners are reluctant to implement measures to lower water consumption in garden irrigation, apparently because of a lack of knowledge regarding more sustainable design alternatives. Homeowners who had prior knowledge of the principles of xeriscaping were significantly more open to applying these principles in practical ways.
\end{abstract}

I n the past, southern European cities were compact, with moderate levels of environmental impact. However, over the past few decades, Spain has experienced an important urban and suburban sprawl process (Dura-Guimera, 2003), characterized by a lack of integrative planning. Strong territorial imbalances and important changes at the socioeconomic level occurred during this period that resulted in landscape transformation. This process often led to low-density development (Benfield et al., 1999), diffuse city models, and the typical characteristics of Anglo-Saxon townplanning, with attending negative environmental impacts (León, 2003).

The low-density model has proved to have a greater environmental impact

The authors greatly appreciate the contributions of Álvaro Gómez, Manuel Jesús Gómez, Alberto Noriega, and María del Carmen Martín to this research project.

${ }^{1}$ Department of Agroforestry Sciences, School of Agricultural Engineering, University of Seville, Carretera de Utrera, Km 1, 41013, Seville, Spain

${ }^{2}$ Department of Forest Engineering, School of Agricultural and Forestry Engineering, University of Cordoba, Edificio Leonardo Da Vinci, Campus de Rabanales, Carretera Nacional IV, Km 396, 14071, Cordoba, Spain

${ }^{3}$ Corresponding author. E-mail: rafafc@us.es. than compact cities with high-density models (Parés-Franzi et al., 2006), so sprawl processes pose an enormous environmental challenge. This phenomenon is not exclusive to Spain or southern Europe (Dura-Guimera, 2003), but is also common to many metropolitan areas in the world, especially in certain regions of the United States (Southworth and Owens, 1993).

The current processes of urban growth and urbanization are environmental challenges that require optimizing the ways in which natural resources are managed and used (ParésFranzi et al., 2006). Numerous studies have examined the implications of urban sprawl and have identified multiple negative impacts it has on almost all environmental parameters (Camagni et al., 2002). These include air quality degradation (Frank, 2000), reduction and degradation of water supplies (Otto et al., 2002), and habitat loss and fragmentation (U.S. Environmental Protection Agency, 2000).

The residential landscape has become a significant portion of the urban environment. Many new residential areas, characterized by low-density development, are based on single-family houses with private gardens, both of which are relatively small in size, but which, when considered jointly, make a substantial contribution to urban green space (Gaston et al., 2005) and have an important impact on the local environment.

Spain has a rich historical heritage with a mixture of cultures, and it is home to some of the most beautiful and ancient European gardens in existence. Today, however, Spanish gardens present some significant problems with regard to design and maintenance, including an inadequate selection of plant species (it is not unusual to find tropical plants requiring excessive water consumption), the misuse of pesticides, poor management of organic waste, and the indiscriminate creation of turf areas (Domene and Saurí, 2003).

The rise of single-family home gardens has also increased water consumption in cities (St. Hilaire et al., 2010). This fact is especially important in southern Europe, where the Mediterranean climate is characterized by periods of drought coinciding with the hot season, during which water consumption reaches its peak, as a result of increased demand in urban areas and because of tourism and agriculture (Parés-Franzi et al., 2006). Concerns about domestic water consumption are increasing in Spain. A study conducted in Madrid, Spain, concluded that homes with a garden consumed, on average, between 2.5 and 4.5 times more water than houses without gardens or flats in the same town (Heras, 2003). Another study conducted in Barcelona,

\begin{tabular}{llll}
\hline $\begin{array}{l}\text { Units } \\
\begin{array}{l}\text { To convert U.S. to SI, } \\
\text { multiply by }\end{array}\end{array}$ & U.S. unit & SI unit & $\begin{array}{l}\text { To convert SI to U.S., } \\
\text { multiply by }\end{array}$ \\
\hline 0.0929 & $\mathrm{ft}^{2}$ & $\mathrm{~m}^{2}$ & 10.7639 \\
25.4 & inch $(\mathrm{es})$ & $\mathrm{mm}$ & 0.0394 \\
1.6093 & mile(s) & $\mathrm{km}$ & 0.6214 \\
2.5900 & $\mathrm{mile}^{2}$ & $\mathrm{~km}^{2}$ & 0.3861 \\
$\left({ }^{\circ} \mathrm{F}-32\right) \div 1.8$ & ${ }^{\circ} \mathrm{F}$ & ${ }^{\circ} \mathrm{C}$ & $\left(1.8 \times{ }^{\circ} \mathrm{C}\right)+32$
\end{tabular}


Spain, found that the irrigation of gardens could be responsible for as much as $16 \%$ of total domestic consumption (Domene et al., 2005).

In the United States, there is an important awareness of garden design and its impact on water consumption, embodied in concepts such as waterwise landscaping and xeriscaping (St. Hilaire et al., 2008). Xeriscaping is a method that emerged in Colorado in 1981 for developing water-wise landscapes and includes seven principles: planning and design, soil analysis, plants with low water needs, creation of practical turf areas, efficient irrigation, mulches, and correct landscape maintenance (Wade et al., 2007). Currently, xeriscaping is commonly implemented in the United States, with programs in several states. In Spain, by contrast, concerns about water use in gardens are relatively new. The concept of xeriscaping was first introduced in Spain in 1991, from the United States (Burés, 1991). Since then, it has appeared and been popularized in several publications, helping its relative diffusion (Burés, 2000; Fundación ecología y desarrollo, 2000; Labajos, 2004). It has also been discussed in numerous administration documents focusing on sustainable gardening practices, published in several Spanish cities and regions (Martín et al., 2004).

All parks and gardens may be considered urban ecosystems whose ecological roles will depend on their configurations and compositions, and whose sustainability can be evaluated according to their functioning. There are several studies regarding the ecological function of green spaces; these usually have focus on large urban green areas. However, few scientific studies have focused on domestic gardens although the available evidence suggests that they play important roles in supporting various wildlife populations (Smith et al., 2005).

Important research on the role of private gardens in urban ecosystems was undertaken in Sheffield, England (Thompson et al., 2003). Multiple factors, such as the typology of the garden, its components, and its influence on biodiversity and ecosystem functioning, were analyzed in that project (Gaston et al., 2005; Smith et al., 2005). In the United States, there have been several studies examining residents' attitudes and preferences toward urban landscapes and water conservation choices (Hurd et al., 2006; Spinti et al., 2004; St. Hilaire et al., 2010; Varlamoff et al., 2001). In Spain, however, few studies have explored this area; among them, the study conducted in the metropolitan area of Barcelona, which examined the relationship of private gardens and water use for irrigation (Domene and Saurí, 2003), stands out.

The goal of this paper is to analyze features and management practices in domestic gardens and to determine the attitudes of garden owners in southern Spain with regard to more sustainable alternatives. In addition, the main features of private gardens were studied.

\section{Materials and methods}

For this study, in-person interviews were conducted with homeowners who possess domestic gardens in the region of Aljarafe in southern Spain.

Study AREA. The Aljarafe region is situated just outside of Seville (lat. $37^{\circ} 23^{\prime} \mathrm{N}$, long. $5^{\circ} 58^{\prime} \mathrm{W}$ ), in the southwest of Spain (Fig. 1), covers an area of $1136 \mathrm{~km}^{2}$, and is composed of 31 municipalities ranging from 5000 to 40,000 inhabitants, with its entire population surpassing 300,000 inhabitants. This fertile area has primarily been an agricultural region over the millennia, with beautiful landscapes of olive (Olea europaea) groves, herbaceous plants, fruit trees, and vineyards (Vitis vinifera). However, this landscape has changed dramatically over the last several decades because of urban sprawl and economic growth in the metropolitan area of Seville (García Brenes and Fernández Cañero, 2011).

In terms of climate classification, the Aljarafe is typically Mediterranean (Kottek et al., 2006), with hot, dry summers and mild winters. The average annual temperature is $18.3^{\circ} \mathrm{C}$. The average annual precipitation is $600 \mathrm{~mm}$, concentrated between the months of November and March (Almarza Mata, 1984). The distribution of rainfall is very irregular and can vary greatly from one year to another, with years of abundant rainfall alternated with cyclic severe droughts.

The survey. To obtain a less biased picture of the features and management practices within domestic gardens in southern Spain, 162 in-person interviews were conducted with owners of homes with gardens. Interviewees were previously chosen, at random, in the Aljarafe region between Apr. 2007 and Mar. 2008. Interviews were conducted at the interviewees' homes or in the sampled gardens.

A direct, face-to-face survey methodology was employed for this project because of the accompanying high level of response from respondents, as compared with other methodologies commonly used to conduct surveys, such as telephone or mailed questionnaires (Crawford, 1997). This methodology allows the interviewer to remain attuned to specific reactions and to even eliminate potential misunderstandings about the questions being asked in the questionnaire (Sheaffer et al., 2005).

To secure a representative sample, the sampling plan was stratified with proportional allocation according to the number of single-family homes in each of the municipalities studied in the Aljarafe region. The households to be surveyed were randomly selected using the random route method. This method gives each house in the area being sampled the same chance of being selected for the survey as any other (Public Opinion Pros, 2007). Only single-family dwellings were filtered with the help of digital mapping information from the municipalities of the region.

The survey consisted of 50 questions and was designed to obtain information relating to: 1) features of the property in relation to the garden; 2 ) design of the garden, and its relationship with the surrounding landscape; 3 ) elements of the garden, with emphasis on the plant species that were selected; 4) efficiency of irrigation and determination of the irrigation system used; 5) distribution of garden areas, in terms of applications and features; 6 ) maintenance management; and 7) knowledge of and attitudes toward xeriscaping. The questions asked in the survey were specifically designed to be nonintrusive. The questionnaire contained multiple choice, dichotomous, and open-ended questions.

Before conducting the statistical analysis, the survey data were recorded and organized using Excel (version 2007; Microsoft, Redmond, WA), and the anomalous data were refined, unfinished surveys being discarded (Hagerhall, 2000). Data were analyzed using SPSS (version 18 for Windows; IBM SPSS, Chicago, IL). 


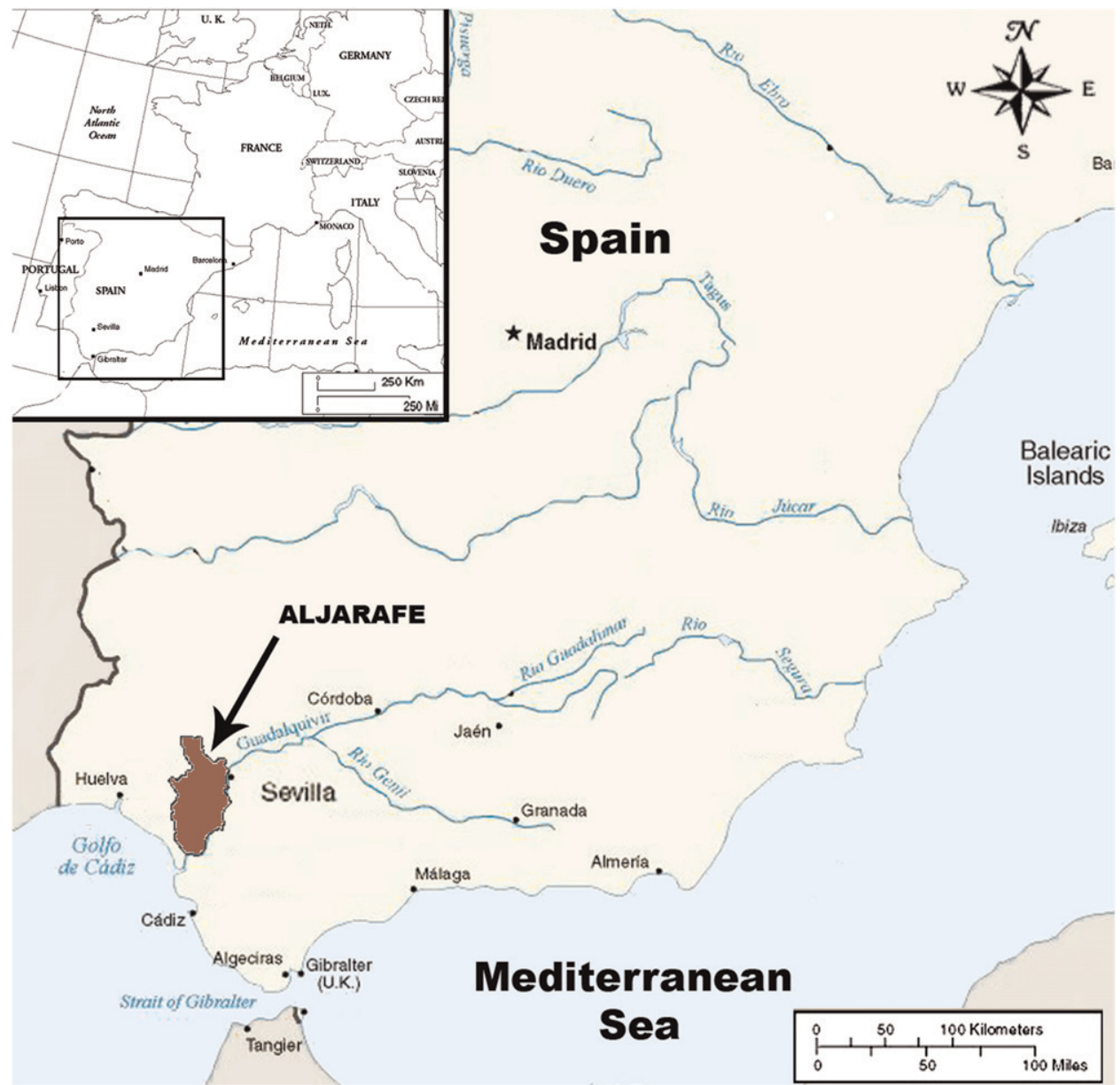

Fig. 1. The approximate position of the Aljarafe region and the city of Seville in southern Spain.

Associations between selected categorical variables were assessed using Kruskal-Wallis $\mathrm{X}^{2}$ and analysis of variance (ANOVA). Nonparametric tests, including Kruskal-Wallis's method, Kendall's tau rank correlation coefficient, and Dunnett's C test were used to analyze the data obtained. Significance was defined at $P \leq 0.05$.

\section{Results and discussion}

GARDENS AND PARCELS AREAS. Of the randomly selected gardens, gardens with areas between 100 and 250 $\mathrm{m}^{2}$ were the most common $[34.78 \%$ (Fig. 2)], and large gardens were relatively infrequent (18.63\%). This contrasts with the fact that parcels exceeding $500 \mathrm{~m}^{2}$ were the most frequent, but only accounted for $31.68 \%$ of the total.

A study of the relationship between gardens area and parcels area was conducted, and it was determined that garden area was strongly related to house parcel size $\left(\chi^{2}=38.768\right.$, $d f=9, P<0.0001)$. There was also a statistically significant nonparametric

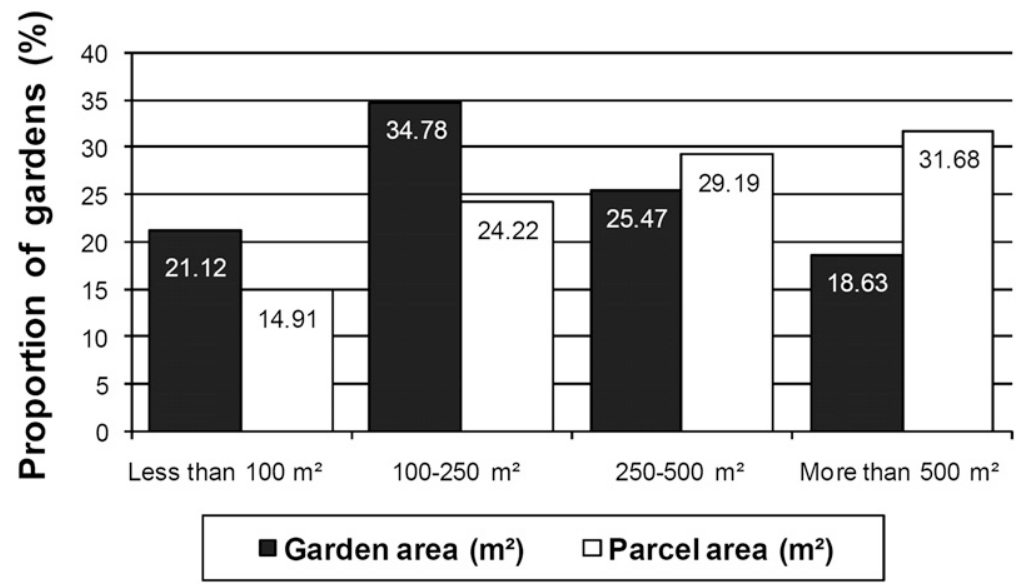

Fig. 2. Comparison of the area of the studied gardens and the area of the parcels where they were located in Aljarafe, Spain; $1 \mathrm{~m}^{2}=10.7639 \mathrm{ft}^{2}$.

correlation (Kendall's tau-b $=0.352$, $P<0.0001$ )

Individual garden area was positively correlated with other important factors, such as turf area of the garden, the existence of automatic garden irrigation, the degree to which the owner took responsibility for landscape maintenance, and time spent on the maintenance of the garden (Table 1).

As it was seen previously, the area of the garden is in turn related to the area of the parcel, and it probably determines many of the decisions of the homeowners surveyed, in terms of garden design and maintenance. 
The relationship between garden area and housing type was also confirmed by the Kruskal-Wallis one-way ANOVA by rank. Gardens of terraced houses and semidetached houses were significantly smaller than those of detached houses (Kruskal-Wallis chisquare $=55.525, \mathrm{df}=2, P<0.0001)$.

Age of the gardens. Garden age is another interesting parameter. Both newly built gardens (at barely 1 year old) and gardens up to 34 years old were found in the homes studied. However, more than two-thirds of surveyed gardens $(70.44 \%)$ were less than 10 years old, which is logical considering that many of these houses are newly constructed, as mentioned earlier in the discussion of the important process of population growth in the Aljarafe region.

GARDEN DESIgN. The initial design is one of the most important aspects that determine the future of a garden and the characteristics of its maintenance. It is essential for any private garden design to meet the needs of those who possess and use it (Alexander, 2004). However, as the first principle of xeriscape states, a wellplanned garden should take into account, in addition to the wishes of the owner, a set of parameters including

Table 1. Effect of individual garden area on garden features and maintenance habits in Aljarafe, Spain $(n=162)$.

\begin{tabular}{|c|c|c|c|}
\hline \multirow[b]{2}{*}{ Features } & \multicolumn{3}{|c|}{ Kendall's rank correlation } \\
\hline & $r^{2}$ & & \\
\hline Turf area of the garden ${ }^{z}$ & 0.582 & & 01 \\
\hline \multirow[t]{2}{*}{ Time spent on the maintenance of the garden ${ }^{\mathrm{z}}$} & 0.268 & & 01 \\
\hline & \multicolumn{3}{|c|}{ Pearson chi-square test } \\
\hline Maintenance habits & $\chi^{2}$ & $d f$ & $P$ \\
\hline $\begin{array}{l}\text { Existence of automatic garden watering system } \\
\text { in the garden }{ }^{y}\end{array}$ & 17.615 & 3 & 0.001 \\
\hline The owners do the landscape maintenance ${ }^{y}$ & 17.092 & 3 & 0.001 \\
\hline
\end{tabular}

Table 2. Features of the garden design reported by private garden owners in Aljarafe, Spain.

\begin{tabular}{lcc}
\hline & \multicolumn{2}{c}{ Proportion of gardens (\%) } \\
\cline { 2 - 3 } Features & Yes & No \\
\hline The owner is the designer & 86.25 & 13.75 \\
Site features and surrounding landscape is considered & 36.67 & 63.33 \\
Landscape designed with areas of differing water & 17.72 & 82.28 \\
$\quad$ requirements (hydrozoning) & & \\
\hline
\end{tabular}

the regional and local climate conditions of the site, topography, existing vegetation, and, especially, the grouping of plants by their water requirements (Wade et al., 2007).

To analyze the features of a garden's design, it is helpful to know the authorship of the design. As can be seen in Table 2 , most of the surveyed gardens $(86.25 \%)$ were designed by their owners.

Garden owners were asked if they had taken into account the site features and the surrounding landscape in the process of their garden design. As shown in Table 2, only onethird of the respondents answered in the affirmative (36.67\%), while the rest $(63.33 \%)$ said they had not considered these factors.

Remarkable is the low presence of gardens in which plants are grouped according to their water needs, at only $18 \%$ (as shown in Table 2 ). This is one of the basic guidelines of xeriscape and contributes significantly to the achievement of efficient irrigation because it promotes the application to each plant of the amount of water that it actually needs (Wade et al., 2007).

Respondents were also asked about the main objectives in the design and construction of the garden; 
confirmed. There was also a statistically significant nonparametric correlation between garden area and number of ornamental trees (Kendall's tau$\mathrm{b}=0.463, P<0.0001)$ and between garden area and number of fruit trees (Kendall's tau-b $=0.425, P<0.0001$ ).

Turfgrass. Turfgrass plants are among the most functional and versatile of all garden plants. They allow the creation of spaces for multiple uses and have important ecological functions such as the reduction of erosion, which allows for the more efficient use of rainwater. It is problematic, however, that lawns often occupy oversized surfaces, and when they are inadequately maintained or when the chosen species are not appropriate for the area, they cause a great deal of water waste (Wade et al., 2007).
In the Mediterranean area, it is almost impossible to create a lawn that will look natural and beautiful all year round. If warm-season perennial grasses are selected, which are well adapted to the heat, the grass will be green and excel aesthetically in summer, but will be brown in the winter. On the other hand, selecting cold-season species will ensure a good appearance in the winter, but in summer will require large water inputs to maintain a minimum ornamental value (Latymer, 2004).

A high percentage of the gardens studied $(79.63 \%)$ had a lawn area. As shown in Fig. 3, the lawn areas were very important and prevalent in garden design.

When comparing lawn area with total garden area (Table 5), it was noted that $71.61 \%$ of the gardens have turf

Table 4. Number of plant species used in the landscape design reported by private garden owners in Aljarafe, Spain.

\begin{tabular}{lccccc}
\hline & \multicolumn{5}{c}{ Proportion of gardens (\%) } \\
\cline { 2 - 6 } Type of plant & \multicolumn{5}{c}{ Plant species in the garden (no.) } \\
\cline { 2 - 6 } & None & $\mathbf{1 - 3}$ & $\mathbf{4 - 6}$ & $\mathbf{7 - 9}$ & $\geq \mathbf{1 0}$ \\
\hline Ornamental trees & 36.42 & 40.74 & 18.52 & 2.47 & 1.85 \\
Fruit trees & 32.72 & 45.98 & 11.73 & 4.94 & 4.94 \\
Shrubs & 11.73 & 37.65 & 37.04 & 6.79 & 6.79 \\
\hline
\end{tabular}

${ }^{2}$ Percentage values may not total 100 because of rounding errors. areas whose surfaces exceed $50 \%$ of the total outdoor landscaped area. This is in opposition to one of the xeriscape guidelines pertaining to the selection of appropriate turf areas, which should be sized to meet the needs of intended use (Wade et al., 2007), and contrasts with the directives set in some U.S. cities, like San Antonio, TX (Bounds, 2009), Brownsville, TX (National Wildlife Federation and the Lone Star Chapter of the Sierra Club, 2010), Las Vegas, NV (Anderson, 2004), or Roseville, CA (Planning and Redevelopment Department of Roseville, 2010), where landscape grass area cannot exceed $50 \%$ of the total area of a landscape.

Species used in lawns were also studied; among the most popular was st. augustinegrass (Stenotaphrum secundatum), which was present in $86.67 \%$ of the sampled gardens. St. augustinegrass is very popular in Spain, especially in coastal areas and in certain inland areas with mild winters. Its resistance to high summer temperatures is quite remarkable, and it forms very dense lawns, but is not as resistant to lack of water as bermudagrass (Cynodon dactylon) (Monje Jiménez, 2009). Bermudagrass stands out for its drought resistance and, grouped

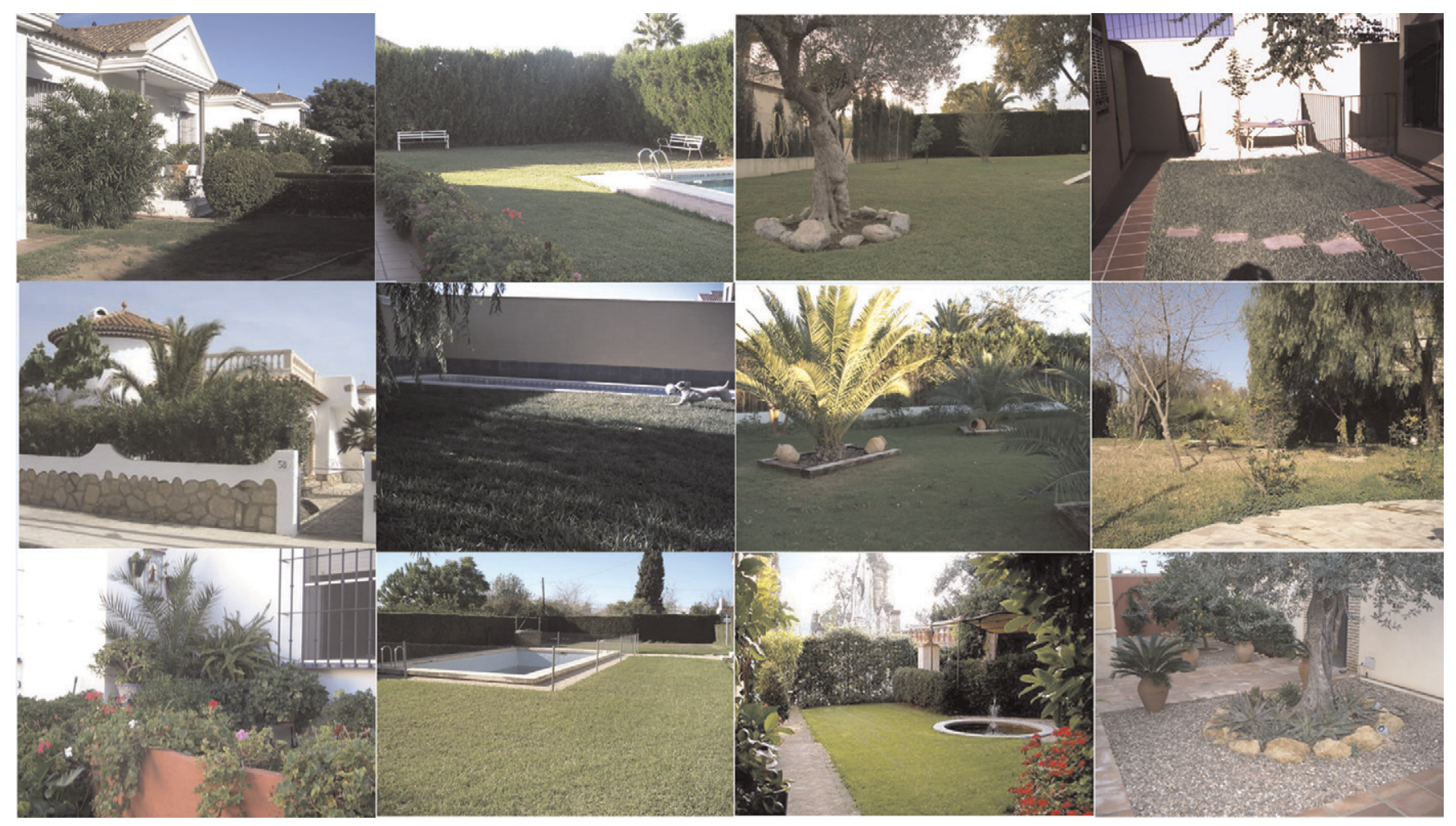

Fig. 3. Collection of images of several gardens sampled in Aljarafe, Spain. 
together with other hybrids of the genus, appears in second place, with a percentage of $8.53 \%$.

Initially, st. augustinegrass would appear not to be a bad choice, especially when compared with cool-season species (present only in $3.10 \%$ of the studied gardens) such as perennial ryegrass (Lolium perenne), fescues (Festuca spp.), or creeping bentgrass (Agrostis spp.), all of which have much higher water requirements. However, if those surfaces were replaced with bermudagrass, water consumption for irrigation could be reduced significantly, improving the ornamental value of the turf areas. In this context, it should be noted that some cities in the southern United States, especially in Florida, have banned the use of st. augustinegrass in its regulations, with the aim of achieving waterwise landscapes (Bounds, 2009).

Landscape management. One of the seven principles of xeriscaping is to properly maintain the garden, and, according to Wade et al. (2007), in the case of following the other six principles, it is much easier and cheaper to accomplish. Fewer pesticides and fertilizers are needed, and less labor is required for maintenance. In addition, many cultural practices can help to save water in gardens, developing more resistant plants.

Owners were also asked who was responsible for maintenance in their gardens. Almost $83 \%$ of respondents were involved in their own maintenance, as shown in Table 6 , with $75 \%$ of them personally performing all maintenance. Professional gardening companies were employed in only $25 \%$ of cases (including the cases in which the owners were collaborating partially in the maintenance of the garden).

GARDEN IRRIgATION. The questionnaire also asked owners about the irrigation systems used in the gardens. Irrigation by aspersion and manual

Table 5. Lawn area comparing with total garden area reported by private garden owners in Aljarafe, Spain.

\begin{tabular}{lc}
$\begin{array}{l}\text { Turfgrass area } \\
\text { (\% total) }\end{array}$ & $\begin{array}{c}\text { Proportion of } \\
\text { gardens }(\%)^{\mathbf{z}}\end{array}$ \\
\hline Without turfgrass & 20.37 \\
$1 \%$ to $25 \%$ & 1.23 \\
$25 \%$ to $50 \%$ & 6.79 \\
$50 \%$ to $75 \%$ & 37.04 \\
$75 \%$ to $100 \%$ & 34.57 \\
\hline
\end{tabular}

${ }^{2}$ Percentage values may not total 100 because of rounding errors. irrigation by hose were used at similar frequency, $60.49 \%$ and $57.41 \%$ respectively. Drip irrigation, however, was barely present, found in 30.86\% of the sampled gardens. This is worrisome because, as noted by Fuentes (2003), drip irrigation has $75 \%$ to $90 \%$ efficiency and sprinkler irrigation systems have an efficiency of $65 \%$ to $85 \%$.

The use of an automatic garden irrigation system allows for greater control, efficiency, and adjustment of the irrigation doses that are applied, achieving a reduction in the cost of general maintenance while saving water (Martín et al., 2004). In the gardens surveyed, as shown in Table 7 , only $57.23 \%$ had automatic irrigation systems. This contrasts with the results of a study on residential end uses of water developed by the America Water Works Association Research Foundation (Mayer et al., 1999), which showed across the United States had automatic watering systems in the garden.

Interviewers also asked respondents if they believed that irrigation that $30.9 \%$ of households sampled

systems in domestic gardens were usually efficient. Most (85.71\%) answered in the affirmative. This could suggest that no general awareness exists that irrigation of private gardens constitutes a problem in terms of the efficiency of the installed systems.

In Seville, because of its Mediterranean climate, rainfall periods are very marked, characterized by dry and hot summers. Summer is, therefore, the season of highest water consumption in the gardens. One hundred percent of respondents affirmed that they considered the season when scheduling irrigation (Table 7).

They were also asked how often they watered their gardens in the summer and winter, and, as shown in Table 8 , almost half of the gardens were watered daily in summer, with a large majority $(70 \%)$ not being watered in winter.

Respondents were asked whether they knew the approximate consumption of water used for irrigation in the summers to irrigate their gardens. Surprisingly, only $5 \%$ gave positive

Table 6. Gardening practices, fertilizer use, and insecticide application in 2008 reported by private garden owners in Aljarafe, Spain and in the United States.

\begin{tabular}{lccc}
\hline & \multicolumn{3}{c}{ Location } \\
\cline { 2 - 4 } Activity & $\begin{array}{c}\text { Aljarafe, } \\
\text { Spain (\%) }\end{array}$ & $\begin{array}{c}\text { Southern United } \\
\text { States } \mathbf{z}(\%)\end{array}$ & $\begin{array}{c}\text { All United } \\
\text { States }^{\mathbf{z}} \text { (\%) }\end{array}$ \\
\hline Homeowners who... & & & \\
$\quad$ do their own landscape maintenance & 83.2 & 91 & 86 \\
apply fertilizer to their landscapes & 80.7 & 31 & 41 \\
apply insecticides to their landscapes & 51.3 & 24 & 22 \\
\hline
\end{tabular}

${ }^{2}$ Data from Varlamoff et al., (2001).

Table 7. Irrigation practices and opinion reported by private garden owners in Aljarafe, Spain.

Activity

Proportion of respondents $(\%)$

Homeowners who...

have automatic garden watering system in the garden

57.23

take into account the season to regulate the irrigation of the garden

know the amount of water consumed in the garden irrigation

100

Homeowners think that...

water consumption in gardens is appropriate/efficient

irrigation systems in domestic gardens are usually efficient

85.71

85.71

Table 8. Proportion of gardens based on the frequency of irrigation in summer and winter reported by private garden owners in Aljarafe, Spain.

\begin{tabular}{lccccc}
\hline & \multicolumn{5}{c}{ Proportion of gardens (\%) } \\
\cline { 2 - 6 } Season & Daily & Alternate days & Every 3 d & Weekly & No irrigation \\
\cline { 2 - 6 } Summer & 48.75 & 36.88 & 13.13 & 1.35 & - \\
Winter & - & - & 8.13 & 21.88 & 70 \\
\hline
\end{tabular}

${ }^{2}$ Percentage values may not total 100 because of rounding errors. 

clear that most respondents did not know what percentage of their water consumption bill was for the irrigation of their garden. Apparently this was a sensitive issue because a significant number of respondents $(26.7 \%)$ refused to answer these questions.

To understand the attitudes of the surveyed owners toward water-wise landscaping, they were asked if they would be willing to change a portion of their grass area to an area of mulch to save water. As shown in Table 9, their responses were overwhelmingly negative (86.09\%). Only $11.26 \%$ stated that they would be willing to do this, and $2.65 \%$ answered that they had already done so. This negative result is probably due to a lack of knowledge regarding the alternatives of design offered through xeriscaping, and their aesthetic and functional possibilities. To delve into this issue, respondents were asked if they had any knowledge of xeriscaping principles, and only $16.88 \%$ responded affirmatively.

It was desired to determine whether respondents who knew the principles of xeriscaping had different attitudes or habits in their gardening practices compared with those who did not. For this purpose, the relationship between the knowledge of xeriscaping

Table 9. Answers to the question: "would you be willing to replace some of the grass area by an area of mulch to save water?" reported by private garden owners in Aljarafe, Spain.

\begin{tabular}{lc}
\hline Answer & $\begin{array}{c}\text { Proportion of } \\
\text { respondents (\%) }\end{array}$ \\
\hline They would not & 86.09 \\
They would & 11.26 \\
They already did & 2.65 \\
\hline
\end{tabular}

responses. Furthermore, it became

principles and other parameters of the survey was studied. The purpose was to determine whether, when garden owners were familiar with these types of more sustainable gardening techniques, there were changes in attitude and implementation of xeriscaping practices. Table 10 shows statistically significant relationships, suggesting that homeowners with knowledge of xeriscaping were more likely to apply this knowledge.

These outcomes are consistent with the results of other investigations, including research carried out in Davis County, UT, where an evaluation of homeowner preferences toward water-wise landscapes was conducted (McCammon et al., 2009), and the conclusion was that knowledge of xeriscaping could influence homeowner attitudes and behaviors toward landscapes under drought stress (McCammon et al., 2009).

\section{Conclusions}

The results of the study reported here indicate that private gardens in the Aljarafe region are designed primarily by their owners, for mainly aesthetic purposes, and usually without considering environmental characteristics.

As regards landscape design, although there is some incorporation of the characteristics of Spanish traditional gardening, including the significant use of fruit trees in gardens, the lawn has a fundamental role in most of the studied gardens. The species most frequently used is st. augustinegrass, which is probably not the species most suited to the climatic conditions of the study area.

In terms of the irrigation of gardens, efficiency is lacking, with $43 \%$ of sampled gardens having no automated irrigation system and drip irrigation

Table 10. Pearson correlation chi-square test comparing the "knowledge of xeriscape" to other parameters of the survey reported by private garden owners in Aljarafe, Spain.

\begin{tabular}{lccc}
\hline & \multicolumn{3}{c}{ The garden owners know the principles of xeriscape } \\
\cline { 2 - 4 } Variables & \multicolumn{3}{c}{ Pearson chi-square test } \\
\cline { 2 - 4 } & 20.99 & 1 & $P$ \\
\hline Hydrozoning design & 4.64 & 1 & $<0.0001$ \\
Automated irrigation & 4.48 & 1 & 0.0312 \\
Using drip irrigation & 8.481 & 1 & 0.0342 \\
Would replace some of the & & & 0.004 \\
$\quad$ grass area by an area of & & & \\
mulch to save water & & & \\
${ }^{2}$ Yates' correction for continuity has been applied to improve the accuracy of $2 \times 2$ test.
\end{tabular}

Yates correction for continuity has been applied to improve the accuracy of $2 \times 2$ test. systems being less frequently used than sprinklers or hoses. However, it has been determined that factors such as total garden area have an influence on various features of the garden and its management, in terms of the existence of automated irrigation or the decision to hire a professional maintenance service.

Finally, it was noted that owner knowledge of xeriscaping seems to have a positive relationship in terms of the practical application of relevant principles in the garden.

\section{Literature cited}

Alexander, R. 2004. The essential garden design workbook. Timber Press, Portland, OR.

Almarza Mata, C. 1984. Fichas hídricas normalizadas y otros parámetros hidrometeorológicos. Instituto Nacional de Meteorología, Madrid, Spain.

Anderson, K.M. 2004. An investigation into what planning departments and water authorities can learn from eleven communities. MS Diss., Univ of Oregon, Eugene. 12 Dec. 2010. <http://scholarsbank.uoregon. edu/xmlui/bitstream/handle/1794/179/ Waterwise\%20Landscaping\%20Ordinances. pdf? sequence $=1>$.

Benfield, F.K., M.D. Raimi, and D.D.T. Chen. 1999. Once there were greenfields: How urban sprawl is undermining America's environment, economy, and social fabric. Natural Resources Defense Council, Washington, DC.

Bounds, G. 2009. Turf battle heats up over limits on water-guzzling landscapes. 12 Dec. 2010. <http://online.wsj.com/ article/SB 10001424052970203278404 574416990861394378.html >.

Burés, S. 1991. El Xeriscape, un nuevo concepto de jardinería. Horticultura 67: 6-11.

Burés, S. 2000. Avances de xerojardinería. Junta de Andalucía-Ediciones de Horticultura, Seville, Spain.

Camagni, R., M. Gibelli, and P. Riagamonti. 2002. Urban mobility and urban form: The social and environmental costs of different patterns of urban expansion. Ecol. Econ. 40:199-216.

Crawford, I.M. 1997. Marketing research and information systems (Marketing and agribusiness texts-4). 12 Dec. 2010. <http://www.fao.org/docrep/W324lE/ w324le00.htm>.

Domene, E. and D. Saurí. 2003. Modelos urbanos y consumo de agua. El riego de jardines privados en la región metropolitana 
de Barcelona. Investigaciones geográficas 32:5-17.

Domene, E., D. Saurí, and M. Parés. 2005. Urbanization and sustainable resource use: The case of garden watering in the metropolitan region of Barcelona. Urban Geogr. 26:520-533.

Dura-Guimera, A. 2003. Population deconcentration and social restructuring in Barcelona, a European Mediterranean city. Cities 20:387-394.

Frank, L.D. 2000. Land use and transportation interaction: Implications on public health and quality of life. J. Plann. Educ. Res. 20:6-22.

Fuentes, J.L. 2003. Técnicas de riego. Ediciones Mundi-Prensa, Madrid, Spain.

Fundación Ecología y Desarrollo. 2000. Guía práctica de la xerojardinería. Fundación Ecología y Desarrollo-Bakeaz, Bilbao, Spain.

García Brenes, M.D. and R. Fernández Cañero. 2011. Ruptura de la sostenibilidad en la comarca del Aljarafe (Sevilla). La dialéctica olivar-urbanización. Scripta Nova-Revista Electronica de Geografia y Ciencias Sociales 15:1-13.

Gaston, K.J., P.H. Warren, K. Thompson, and R.M. Smith. 2005. Urban domestic gardens (IV): The extent of the resource and its associated features. Biodivers. Conserv. 14:395-413.

Hagerhall, C.M. 2000. Clustering predictors of landscape preference in the traditional Swedish cultural landscape: Prospect-refuge, mystery, age and management. J. Environ. Psychol. 20:83-90.

Heras, F. 2003. Jardinería con menos agua. Ambienta 25:50-52. 20 Sept. 2006. <http://www.mma.es/secciones / medios_comunicacion/revista_ambienta/ n25/pdf/50_52_ecologia_vida_25.pdf>.

Hurd, B., R. St. Hilaire, and J. White. 2006. Residential landscapes, homeowner attitudes and water-wise choices in New Mexico. HortTechnology 16:241-246.

Kottek, M., J. Grieser, C. Beck, B. Rudolf, and F. Rubel. 2006. World map of the Köppen-Geiger climate classification updated. Meteorologische Zeitschrift 15: 259-263

Labajos, L. 2004. Manual de jardinería ecológica. Ecologistas en Acción, Madrid, Spain.
Latymer, H. 2004. El jardín mediterráneo. Editorial Naturart, Barcelona, Spain.

León, R. 2003. Un nuevo urbanismo para Andalucía. Consejerías de Medio Ambiente y Educación y Ciencia de la Junta de Andalucía, Seville, Spain. Aula Verde, ${ }^{\circ} 25$. 20 May 2010. <http://www.um.es/gtiweb/ allmetadata/nuevo\%20urbanismo.htm>.

McCammon, T.A., S.T. Marquardt-Pyatt, and K.L. Kopp. 2009. Water-conserving landscapes: An evaluation of homeowner preference. J. Ext. 47(2). 12 Dec. 2010. <http://www.joe.org/joe/2009april/ rb5.php>.

Martín, A., R. Ávila, Mª.C. Yruela, R Plaza, A. Navas, and R. Fernández. 2004. Manual de riego de jardines. Editorial de la Consejería de Agricultura y Pesca, Junta de Andalucía, Seville, Spain.

Mayer, P.W., W.B. De Oreo, E.M. Optiz, J.C. Kiefer, W.Y. Davis, B. Dziegielewski, and J.O. Nelson. 1999. Residential end uses of water. Amer. Water Works Assn. Res. Foundation, Denver, CO.

Monje Jiménez, R. 2009. Céspedes ornamentales y deportivos. Editorial de la Consejería de Agricultura y Pesca, Junta de Andalucía, Seville, Spain.

National Wildlife Federation and the Lone Star Chapter of the Sierra Club. 2010. Drop by drop: Seven ways Texas cities can conserve water. 12 Dec. 2010. <http://www.texaswatermatters.org/ pdfs/DropByDrop.pdf $>$.

Otto, B., K. Ransel, J. Todd, D. Lovaas, H. Stutzman, and J. Bailey. 2002. Paving our way to water shortages: How sprawl aggravates the effects of drought. 22 May 2009. <http://www.americanrivers.org/ assets/pdfs/reports-and-publications / PavingOurWayToWaterShortages4ae6. pdf $>$.

Parés-Franzi, M., D. Saurí-Pujol, and E. Domene. 2006. Evaluating the environmental performance of urban parks in mediterranean cities: An example from the Barcelona metropolitan region. Environ. Manage. 38:750-759.

Planning and Redevelopment Department of Roseville. 2010. Water efficient landscape ordinance (WELO). 12 Dec. 2010. <http://www.roseville.ca.us/civica/ filebank/blobdload.asp?BlobID = 15565> .
Public Opinion Pros. 2007. Glossary. 5 May 2009. <http:/ /www.publicopinionpros. norc.org/glossary/2007/apr/glossary.asp>.

Sheaffer, R.L., W. Mendenhall, and L. Ott. 2005. Elementary survey sampling. Duxbury Press, Boston.

Smith, R.M., K.J. Gaston, P.H. Warren, and K. Thompson. 2005. Urban domestic gardens (V): Relationships between landcover composition, housing and landscape. Landscape Ecol. 20:235-253.

Southworth, M. and P.O. Owens. 1993. The evolving metropolis: Studies of community, neighborhood, and the street form at the urban edge. J. Amer. Planning Assn. 59:271-287.

Spinti, J.E., R. St. Hilaire, and D. VanLeeuwen. 2004. Balancing landscape preferences and water conservation in a desert community. HortTechnology 14: 72-77.

St. Hilaire, R., M.A. Arnold, D.C. Wilkerson, D.A. Devitt, B.H. Hurd, B.J. Lesikar, V.I. Lohr, C.A. Martin, G.V. McDonald, R.L. Morris, D.R. Pittenger, D.A. Shaw, and D.F. Zoldoske. 2008. Efficient water use in residential urban landscapes. HortScience 43: 2081-2092.

St. Hilaire, R., D.M. VanLeeuwen, and P. Torres. 2010. Landscape preferences and water conservation choices of residents in a high desert environment. HortTechnology 20:308-314.

Thompson, K., A. Kevin, R.M. Smith, P.H. Warren, P.G. Angold, and K.J. Gaston. 2003. Urban domestic gardens (I): Putting small-scale plant diversity in context. J. Veg. Sci. 14:71-78.

U.S. Environmental Protection Agency. 2000. Our built and natural environments: A technical review of the interactions between land use, transportation and environmental quality. U.S. Environ. Protection Agency, Washington, DC.

Varlamoff, S., W.J. Florkowski, J.L. Jordan, J. Latimer, and K. Braman. 2001. Georgia homeowner survey of landscape management practices. HortTechnology 11:326331 .

Wade, G.L., J.T. Midcap, K.D. Coder, G. Landry, A.W. Tyson, and N. Weatherly. 2007. Xeriscape, a guide to developing a water-wise landscape. 12 Aug. 2011. <http://www.marex.uga.edu/advisory/ Library/CSCPpdfs/Xeriscape.pdf> 